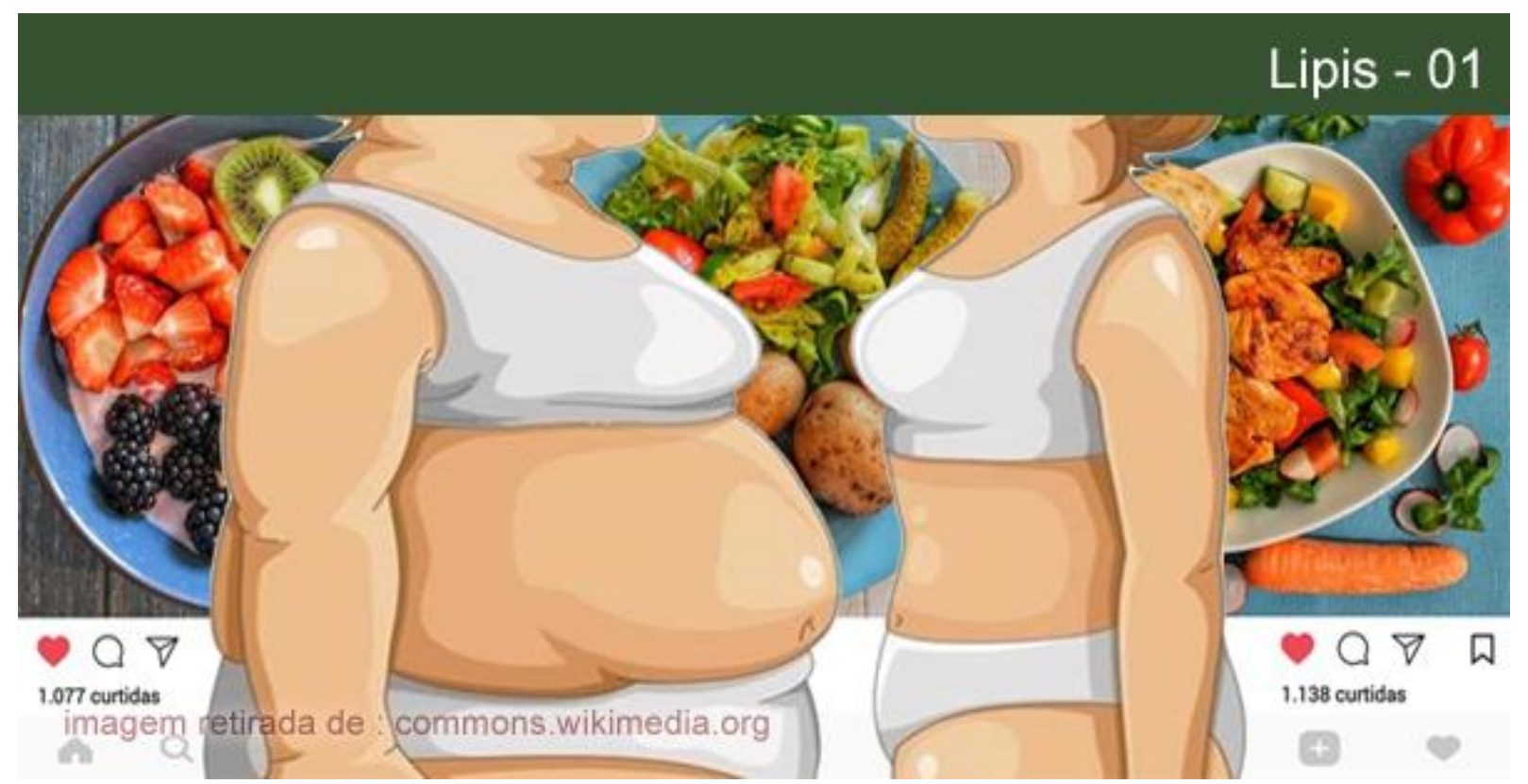

\title{
DO OLHAR AO FAZER CRIATIVO NO UNIVERSO DAS \#INSTAFITNESS
}

\section{Bruna Madureira}

Psicóloga clínica (PUC-Rio). Doutora e Mestre em Psicologia Clínica pela Pontifícia Universidade Católica do Rio de Janeiro (PUC-Rio). Pesquisadora e psicóloga do Laboratório Interdisciplinar de Pesquisa e Intervenção Social (LIPIS) da PUC-Rio. E-mail: bruna.madureira@hotmail.fr.

Resumo: O objetivo do presente artigo é analisar de que maneira o universo feminino se apropria da rede social, principalmente do Instagram, que funciona como um diário de tela para eliminar gordura. Para isso, traçou-se uma analogia entre os conceitos de Donald Winnicott, destacando a função do olhar do outro enquanto constitutivo da representação de si mesmo. Além disso, analisou-se, ainda, conceitos tais como a mãe suficientemente boa e o espaço potencial como metáforas para a experiência em rede proporcionada pela interação com as seguidoras virtuais que curtem, comentam e compartilham as imagens postadas nas redes sociais. Baseadas nas ideias winnicottianas e na observação acerca da comunicação entre as instafitness e suas seguidoras, concluiu-se que o olhar que se dirige para a autoimagem compartilhada é essencial no processo de perda de peso, sobretudo porque esse olhar virtual ganha uma dimensão extremamente positiva. Daí a criação do conceito de seguidoras suficientemente boas.

Palavras-chave: Instafitness. Brincar. Espaço Potencial. Seguidoras suficientemente boas.

\section{FROM THE GAZE TO THE CREATIVE USE OF THE \#INSTAFITNESS UNIVERSE}

Abstract: This article aims to analyze the way the female universe uses social media, especially Instagram, which functions as virtual screen journal of working towards thinness. For that we trace an analogy between Donald Winnicott's concepts, highlighting the function of the followers' gaze as a constitutional representation of the self. We will also analyze the concepts "good enough mother" and "potential space" as metaphors for how the network experience comes from interacting with virtual followers who like, comment and share the images posted in social networks. Based on the Winnicottian ideas and observations of communications between the instafitness users and their followers, we come to the conclusion that the gaze upon one's shared image is essential in the process of weight loss, especially because this virtual gaze becomes extremely positive. Hence the creation of the concept of good enough followers.

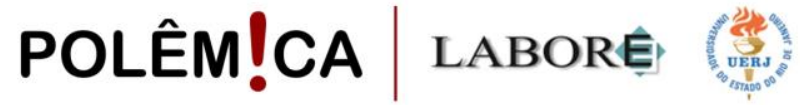

Polêmica - Revista Eletrônica da Uerj - Rua São Francisco Xavier, 524, $1^{\circ}$ andar bloco D, sl.1001 • Tels.: +55 21 2334-4088/4087 • http://www.e-publicacoes.uerj.br/index.php/polemica/index http://www.labore.uerj.br • laboreuerj@yahoo.com.br 
Keywords: Instafitness. Playing. Potential Space. Good enough followers.

\section{Introdução}

O surgimento da internet na década de 60 e a sua exponencial popularização tem se constituído como um dos mais significativos fenômenos culturais da atualidade. O impacto da criação deste aparato tecnológico pode ser facilmente observado em diversas áreas, sobretudo no comportamento humano. É interessante notar como, no decorrer dos anos, a internet tornouse um espaço particularmente importante para construção das relações humanas. A vida social ganha novos contornos a partir da invenção dessa ferramenta, que tem a capacidade de maximizar o contato entre as pessoas, aproximar conhecidos ou desconhecidos e reduzir distâncias, de modo a transformar completamente a experiência espaço-temporal. Em tempos de acelerados avanços tecnológicos, interações antes inimagináveis ocorrem hoje de maneira muito simples e são vivenciadas de maneira instantânea ${ }^{1}$.

Algumas das implicações que a internet trouxe para o ser humano foram as transformações subjetivas geradas a partir do uso desta nova ferramenta como, por exemplo, o surgimento de comunidades virtuais (blogs, salas de bate-papo e redes sociais). Ao adentrar o mundo online, o sujeito modifica completamente a sua forma de ser e estar no mundo. Com isso, o relacionamento entre as pessoas passa a ser mediado pela rede constituída através da internet (SIBÍLIA, 2015). A criação de comunidades é uma das características mais marcantes da internet, pois ela cria uma nova forma de interação - a virtual - mediada pelo aparato tecnológico. Assim sendo, essa nova forma de ser e estar no mundo é incorporada no dia a dia do sujeito contemporâneo e um dos resultados mais notáveis é que a sociabilidade passa a ser dinamizada pela rede, que carrega uma conexão ilimitada e a instantaneidade enquanto premissas básicas.

O homem apropriou-se da tecnologia e incorporou suas características. A internet passou a fazer parte da vida do ser humano de maneira tão intensa quanto natural. Ao integrála em seu cotidiano, o homem automaticamente passa a fazer parte daquilo que cria. Desse modo, sujeito e objeto tornam-se inter-conectados em um grande continuum, conforme

\footnotetext{
${ }^{1}$ Apesar de cientes dos aspectos prejudiciais do uso excessivo da internet e de suas implicações, escapa ao objetivo deste trabalho discutir o uso abusivo da tecnologia na vida dos sujeitos.
}

\section{POLÊM!CA $\mid$ LABORE}

Polêmica - Revista Eletrônica da Uerj - Rua São Francisco Xavier, 524, $1^{\circ}$ andar bloco D, sl.1001 • Tels.: +55 21 2334-4088/4087 • http://www.e-publicacoes.uerj.br/index.php/polemica/index http://www.labore.uerj.br • laboreuerj@yahoo.com.br 
Carvalho aponta: "o objeto carrega em si algo do ser que o criou" (2000, p. 129). O elo que se estabeleceu entre o homem e a máquina é tão íntimo e poderoso que existe um impacto profundo e recíproco entre ambos. Não é apenas o ser humano que molda a tecnologia, ele também é moldado por ela. Ao criar o objeto, homem passa a ser fortemente influenciado por sua criação.

É curioso o quanto o ser humano sofre modificações a partir do uso da sua própria obra. Ainda segundo Carvalho, "sujeitos e objetos emergem simultaneamente em uma causalidade recíproca" (2000, p. 126). Se homem e máquina se vinculam de forma dialógica, ao interferir no objeto tecnológico, ele simultaneamente se transforma a partir da influência da mesma intervenção. Assim sendo, a técnica passa a fazer parte do seu processo de subjetivação.

Se a tecnologia transformou a vida do sujeito contemporâneo a partir da invenção da internet, ela foi responsável por modificar completamente as formas de ser e estar no mundo. Esse novo cenário, por sua vez, reflete na construção de uma subjetividade muito distinta da que vinha sendo constituída até então, calcada no concreto e no físico. Além da possibilidade de conectar-se instantaneamente com o outro, a rede reduziu a noção espaço-temporal e tornouse uma das principais formas de se comunicar com o mundo (LEVY, 1999).

As redes sociais, os sites de relacionamento e canais de informação se converteram em ferramentas essenciais de acesso ao outro e de busca de conteúdo. Com isso, o que se percebe é que as pessoas se conectam cada vez mais através de aplicativos ou gadgets, cuja finalidade é a troca de informação, obtenção de prazer, encontro com o outro, etc. É interessante notar o quanto o universo virtual ganhou uma dimensão central na vida das pessoas, que passam a incorporar o celular em suas vidas como uma espécie de prótese corpórea, ganhando status de tão fundamental quanto os demais membros do seu corpo (ASSUNÇÃO, JORGE, 2014).

Nessa perspectiva, estar na rede significa incluir-se em um universo de informação, sociabilidade e pertencimento. Cada vez mais percebe-se o quanto as redes sociais funcionam como um dos principais espaços de sociabilidade na contemporaneidade. Se as pessoas passam cada vez mais tempo em frente às telas, sobretudo do celular, a sua relação com o mundo passa a ser mediada por essa série de aplicativos, naturalmente instalados em seus aparelhos e que funcionam como uma porta de entrada para o mundo. Diversos são os usos que podem ser feitos das redes sociais: compartilhar conteúdos políticos, vida pessoal ou profissional, procurar uma posição no mercado de trabalho, buscar um profissional específico, promover uma atividade ou um trabalho, encontrar uma pessoa distante, manter contato profissional, etc. (COELHO, 2016).

\section{POLÊM!CA $\mid$ LABORE}

Polêmica - Revista Eletrônica da Uerj - Rua São Francisco Xavier, 524, $1^{\circ}$ andar

bloco D, sl.1001 • Tels.: +55 21 2334-4088 / 4087 • http://www.e-publicacoes.uerj.br/index.php/polemica/index http://www.labore.uerj.br • laboreuerj@yahoo.com.br 
Esse artigo reflete a pesquisa de doutorado da autora, cujo objetivo é analisar de que maneira o universo feminino usa a rede social, sobretudo o Instagram e o Snapchat, para eliminar gordura. Para isso, foram entrevistadas 28 mulheres de diversos estados do Brasil que emagreceram de 10 a 80 quilos no espaço de tempo de um ano e que optaram por usar, exclusivamente, uma conta fitness para emagrecer, o que significa que escolheram dizer não à intervenção cirúrgica (MADUREIRA, 2015). Essas mulheres encontraram no mundo online um espaço de acolhimento da sua dor que não era possível encontrar em suas vidas off-line. A angústia de serem gordas em um mundo cada vez mais aversivo à gordura, sobretudo no universo feminino, as fizeram buscar ferramentas para emagrecer com a finalidade de se encaixarem em um modelo normativo social que vê na anorexia branda, cujo IMC (índice de massa corporal) é 17,5, sinônimo de beleza, saúde e bem-estar (NOVAES, 2006).

É interessante notar o quanto a tecnologia funciona como instrumento contemporâneo de emagrecimento. A partir do compartilhamento diário de imagens com conteúdos alimentares e de exercícios físicos, as instafitness encontram, pela primeira vez em suas vidas, um lugar de pertencimento no mundo. Isso se dá através do encontro com o semelhante que atravessa a mesma dificuldade em virtude do excesso de peso: a exclusão social (MADUREIRA, 2015). O sujeito gordo/obeso é constantemente visto como descontrolado e cujo caráter é falho. Frequentemente julgado como aquele incapaz de produzir no ambiente profissional, ou de seduzir ou dar prazer ao sexo oposto; ao obeso resta ocupar o lugar de chacota, piada e “engraçadinho da turma” (NOVAES, 2006). Em outras palavras, sua única forma de ser e existir no mundo é no lugar de marginalidade da sociedade. Não é à toa que cresce cada vez mais o número de mulheres que buscam instrumentos virtuais como ferramenta para a eliminação de peso.

Os aparatos tecnológicos permitem que o sujeito contemporâneo encontre outras formas de subtrair gordura, o que inclui a criação de um diário de tela éxtimo (SIBÍLIA, 2008), cuja finalidade é postar as dificuldades e o sofrimento do seu dia a dia, que envolvem a mudança dos hábitos alimentares e físicos. Com isso, se abre uma imensa janela de possibilidades e opções para essas mulheres, antes frequentemente restritas, tolhidas e castradas, seja pela família, seja pela rede de amigos. Ao entrarem na rede com o objetivo de perder peso, encontram pessoas que também estão na mesma labuta, pessoas que já emagreceram e que, por isso, funcionam como um modelo social de conquista a ser seguido. Além disso, são pessoas

\section{POLÊM!CA $\mid$ LABORE}

Polêmica - Revista Eletrônica da Uerj - Rua São Francisco Xavier, 524, $1^{\circ}$ andar

bloco D, sl.1001 • Tels.: +55 21 2334-4088/4087 • http://www.e-publicacoes.uerj.br/index.php/polemica/index http://www.labore.uerj.br • laboreuerj@yahoo.com.br 
que como elas também sentem uma enorme dificuldade de mudar hábitos alimentares ou mesmo de seguir uma rotina restritiva de calorias e, por fim, pessoas que compartilham o imenso sofrimento psíquico em virtude de viverem em uma sociedade altamente lipofóbica (VILHENA, NOVAES, ROSA, 2016).

No cenário acima descrito, constata-se o quanto o grupo ganha dimensão essencial na vida dessas mulheres, que passam a conectar-se com a imagem que o outro compartilha, percebendo o quanto isso tem de similar com a sua luta pelo emagrecimento. Ao identificar-se com o sofrimento do outro, que também é seu, é possível, pela primeira vez em suas vidas, realizar um trabalho contínuo em seus corpos com o objetivo de alcançarem a aparência dos seus sonhos, que reflete um corpo magro, jovem e definido. Isso se dá porque a pessoa na qual a instafitness passa a se relacionar é selecionada com base em sua performance virtual, ou seja, se conquistou ou não a aparência supostamente ideal (MADUREIRA, 2015).

O que se verifica é que a força do grupo é poderosa, na medida em que o olhar do outro virtual legitima a existência do sujeito e, com isso, positiva a sua busca pelo emagrecimento, de tal modo que funciona como uma mola propulsora de motivação para permanecer de forma contínua na luta pelo corpo "perfeito". Daí a enxurrada de resultados positivos compartilhados na rede. Se a união faz a força, ela é uma das grandes responsáveis pela mudança de vida dessas mulheres, constantemente marginalizadas em virtude do excesso de gordura.

Além disso, observa-se, ainda, que postar diariamente as condutas alimentares e físicas faz com que se congele no tempo e no espaço o comportamento e o estilo de vida dessas mulheres, o que resulta em uma possibilidade de observarem a quantidade e qualidade dos alimentos ingeridos, bem como os seus hábitos físicos. Isso, por sua vez, facilita a tomada de consciência e a implicação no próprio comportamento que conduz à obtenção de peso, como o seguinte depoimento: "eu sempre soube que comia muito doce, mas foi só postando tudo o que eu comia no Instagram que eu tive noção de que eu comia muito mais açúcar do que eu imaginava [...] isso foi surpreendente" (MADUREIRA, 2015, p. 19). Constata-se, portanto, que congelar a imagem na rede é uma forma de conhecer os seus próprios hábitos de consumo, o que conduz a um maior monitoramento do seu comportamento, bem como controle das práticas alimentares e físicas.

Como consequência, aumenta-se a rigidez da autovigilância, tendo em vista que o outro virtual inspeciona e fiscaliza o seu comportamento 24 horas por dia, ganhando uma dimensão

\section{POLÊM!CA $\mid$ LABORE}

Polêmica - Revista Eletrônica da Uerj - Rua São Francisco Xavier, 524, $1^{\circ}$ andar

bloco D, sl.1001 • Tels.: +55 21 2334-4088/4087 • http://www.e-publicacoes.uerj.br/index.php/polemica/index http://www.labore.uerj.br • laboreuerj@yahoo.com.br 
de vistoria da sua vida muito maior do que imaginada. É a partir desse potencial controle do outro virtual que a instafit não quer correr o risco de decepcioná-lo, afinal de contas ele não é apenas o seu modelo de inspiração, mas o seu grande motivador para eliminar gordura, que constrói um novo olhar para si própria. Isso envolve uma nova rotina de hábitos alimentares e de exercícios físicos, cujos resultados refletem o aumento da autoestima e da segurança com relação ao seu corpo e ao seu potencial enquanto sujeito. Essa realidade conduz muitas mulheres a experienciarem a vida de uma maneira muito distinta da que vinha ocorrendo até então, repleta de dor e sofrimento. Uma nova forma de ser e estar no mundo é construída a partir da mudança de posição que passam a ocupar em suas vidas em virtude do novo corpo que é alcançado.

Essa perspectiva só é possível quando um outro exerce uma função acolhedora e afetuosa para com a sua aflição e padecimento, ainda que seja um outro virtual. Se o mundo off-line não cria condições de amparo para um sujeito obeso que se sente muito solitário, abandonado e desprotegido, é a rede que acaba exercendo esse papel de proteção, refúgio e asilo através de uma escuta virtual que transparece na escrita, como os comentários afetuosos acerca das fotos compartilhadas pelas instafits. São essas formas de reconhecimento da dor, de socorro de sua angústia e de assistência com relação ao seu sofrimento que funcionam como base e apoio. Assim sendo, cada curtida é vivida como um anteparo para a sua agonia, cada comentário positivo é visto como um suporte para a sua aflição e cada compartilhamento da sua foto é sentido não apenas como um reconhecimento da sua luta em direção ao emagrecimento, mas, sobretudo, como uma âncora para manter-se nesse caminho, proporcionando uma segurança psíquica. Com efeito, isso parece constituir uma estratégia de sobrevivência que diz respeito ao luto por ser excluída socialmente e inclui o combustível para trilhar o caminho do emagrecimento.

\section{Seguidoras suficientemente boas}

O olhar do outro pode ser entendido como uma função especular humana (WINNICOTT, 1975). A partir de observações acerca do comportamento e do afeto refletidos pelo espelho humano, ocorrerá uma identificação com esse olhar que o outro me devolve acerca de mim mesmo. Se a superfície lisa e polida do espelho físico reflete a nossa imagem, o espelho humano, de um modo bastante semelhante, funciona igualmente como um sistema de espelhos paralelos que reflete o que o outro "pensa" e "sente" sobre a imagem diante de si. Esse nível

\section{POLÊM!CA | LABORE}

Polêmica - Revista Eletrônica da Uerj - Rua São Francisco Xavier, 524, $1^{\circ}$ andar

bloco D, sl.1001 • Tels.: +55 21 2334-4088/4087 • http://www.e-publicacoes.uerj.br/index.php/polemica/index http://www.labore.uerj.br • laboreuerj@yahoo.com.br 
especular é inerente às relações humanas, ao mesmo tempo em que é sede de importantes funções psicossomáticas, terapêuticas, criativas etc., como aponta Doin (2001).

Segundo Winnicott (1975), ao olhar-se no espelho, o sujeito busca respostas acerca de si mesmo, como, por exemplo, quem ele é. Portanto, assim como no mito do Narciso, ao verse refletido na imagem diante de si, o sujeito identifica-se com ela, como se esta espelhasse uma verdade sobre o seu ser. A função especular humana resulta de uma relação bi ou multipessoal, em que pelo menos um dos participantes espelha a imagem do outro. Na maioria dos casos ocorre uma permuta da ação especular, ou seja, cada participante exerce o papel de espelho para o outro, com maior ou menor predominância. Em comparação com o espelho físico, o espelho humano, por mais realista que seja, está sujeito a deformações em virtude das suas características pessoais, anseios e expectativas, angústias e defesas. Assim sendo, a função especular humana depende ativamente de ambos os participantes, o que inclui tanto os que observam quanto os que são observados, tendo em vista que ambos integram um sistema de transmissão-recepção de imagens e informações responsáveis pela autorregulação e feedback (DOIN, 1987).

O espelho reflete o conjunto bem organizado (ou não) de respostas do outro, que pode ser materno, paterno ou, como no caso das instafitness, um outro virtual. As respostas se dão através de expressões verbais, extraverbais, mímicas, gestos e atitudes, condizentes com as demandas e peculiaridades do ser diante de si (bebê, criança, adolescente ou adulto) (DOIN, 2001). No caso específico das instafitness, o olhar do outro ratifica o quanto ela se tornou um modelo a ser seguido. É justamente esse olhar virtual que, ao acreditar em seu potencial, faz com que ela acredite nela mesma e continue em sua luta para eliminar gordura. Observa-se o quanto o olhar do outro, ainda que desconhecido e representado por curtidas, comentários positivos acerca de sua performance, altera radicalmente o olhar que a instafitness tem sobre ela mesma (MADUREIRA, 2015). No caso do bebê, é justamente esse conjunto de respostas que fornecem ao sujeito uma imagem somato-psíquica integrada do seu ser, ainda que muito incipiente. Isso se dá através de atos delicados e afetuosos para consigo, que refletem um olhar cuidadoso, carinhoso e amoroso (DOIN, 1987). No caso das instafitness, esse conjunto de respostas fornece uma possibilidade, ainda que muito embrionária, de construir internamente sentimentos sólidos, como a segurança e autoestima, há muito dilacerados em virtude do

\section{POLÊM!CA | LABORẸ}

Polêmica - Revista Eletrônica da Uerj - Rua São Francisco Xavier, 524, $1^{\circ}$ andar bloco D, sl.1001 • Tels.: +55 21 2334-4088/4087 • http://www.e-publicacoes.uerj.br/index.php/polemica/index http://www.labore.uerj.br • laboreuerj@yahoo.com.br 
excesso de gordura, que representa uma forma de exclusão social na contemporaneidade (MADUREIRA, 2015).

Em ambos os casos, no entanto, esse olhar alteritário, seja ele virtual ou não, cria possibilidades de um processo identificatório. Isto é, o sujeito é capaz de identificar-se com essa imagem que vê refletida diante de si, e que vai ao encontro de sua disposição profunda, que resultará na definição de sua própria identidade. Se a mãe, através do seu afeto e empatia, funciona como se fosse um espelho suficientemente regular e polido, no qual o seu bebê obtém de si mesmo uma imagem pessoal crescentemente diferenciada e integrada (DOIN, 1987), o olhar virtual, igualmente através da ternura e dedicação, também funciona como um espelho virtual no qual a instafitness reconhece a sua imagem refletida, que se constrói passo a passo através da interação com esse outro virtual, que se baseia na crescente confiança que se estabelece através do vínculo que é feito (MADUREIRA, 2015).

Portanto, a estruturação da identidade é alcançada através do jogo de identificações entre emissor e receptor da imagem. Através da percepção da imagem projetada e refletida na mãe com certa veracidade que persiste apesar de inevitáveis distorções e flutuações psíquicas de ambos os lados, o bebê, lenta e oscilantemente, desenvolve a sua autopercepção e autoestima, graças a uma capacidade de autenticação do seu ser através do olhar do outro que legitima a sua existência, sentimentos, dores, alegrias, etc. (DOIN, 2001). No cenário das instafitness, o que se percebe é que esse olhar alteritário que autentica a sua existência parece estar ausente, ao menos em seu mundo físico, o que faz com que recorram ao universo virtual com a finalidade de encontrarem um ambiente que acolha as suas dores e angústias relativas à obesidade. Se a vivência especular humana opera desde o início da vida infantil e, portanto, na aquisição do self, o que se nota nessas mulheres é um self muitas vezes destruído, em virtude de suas experiências dentro de um corpo gorduroso que reflete sofrimento psíquico como consequência da exclusão social (menos valia, falha de caráter, menos feminina, incapaz de seduzir ou dar prazer ao sexo oposto, redução da produção profissional, etc.) (NOVAES, VILHENA, 2010).

Sublinhamos o quanto que, apesar de semelhante, a função especular humana se diferencia do espelho físico na medida em que é bilateralmente ativa, ou seja, emissor e receptor da imagem interagem entre si e, através dessa comunicação, orientam e modificam o comportamento ou olhar do outro. Na relação mãe-bebê, por exemplo, o bebê guia a mãe no

\section{POLÊM!CA | LABORẸ}

Polêmica - Revista Eletrônica da Uerj - Rua São Francisco Xavier, 524, $1^{\circ}$ andar

bloco D, sl.1001 • Tels.: +55 21 2334-4088 / 4087 • http://www.e-publicacoes.uerj.br/index.php/polemica/index http://www.labore.uerj.br • laboreuerj@yahoo.com.br 
que se refere a erros e acertos de sua conduta materna em sua maneira de vê-lo e lidar com ele. Isso significa que é o bebê quem ensina a mãe a tratá-lo e, posteriormente, retratá-lo. Como consequência, o bebê pode, ainda, funcionar como um espelho integrador da pessoa da mãe (DOIN, 1987).

Entendemos que isso também se aplica às instafitness que, excessivamente fragilizadas e vulneráveis, utilizam a rede social, ainda que inicialmente de forma anônima (sem identificação de rosto ou de nome) para compartilharem a sua dor. No universo virtual, selecionam os seus seguidores e, de certa forma, também os ensinam como gostariam de ser tratadas, o que reflete na inclusão de determinados seguidores. São justamente esses seguidores virtuais que positivam a sua existência, a sua capacidade ou potencial de emagrecimento ou, de maneira análoga, dedicam o seu tempo a tecer exclusivamente comentários negativos acerca do seu formato corpóreo (MADUREIRA, 2015).

Se, em um primeiro momento, o bebê vê a si mesmo e se sente da maneira como os pais, especialmente a mãe, o vê e sente, em um segundo momento, o que se percebe é a busca por uma autonomia gradativa. Se o ambiente facilitador permite a esse bebê crescer em seu ritmo próprio, com o auxílio materno (que inclui as suas falhas) o bebê vai, gradativamente, reduzindo a sua dependência absoluta face ao espelho materno e, automaticamente, aumentando a sua própria função especular interna, isto é, a sua capacidade de autorreflexão. Isso significa refletir e manter a sua identidade e autoestima com relativa independência de objetos espelhadores externos. Como resultado, a criança constrói um caminho para a autonomia interna (DOIN, 2001).

No contexto das instafitness, verificamos uma dependência inicial muito significativa com relação ao olhar do outro virtual, o que parece fazer todo o sentido na medida em que o mesmo era inexistente em suas vidas antes da criação da conta fitness virtual. Então, o que se constata é que esse olhar virtual alteritário ganha uma dimensão essencialmente importante na vida dessas mulheres, uma vez que reflete com cuidado e afeto a sua experiência como obesa em um mundo cada vez mais lipofóbico. Porém, após um intenso trabalho de eliminação de gordura que, no caso da presente pesquisa, durou cerca de um ano, o que se observa como resultado é uma redução da dependência absoluta do olhar virtual, como consequência da construção de uma função especular interna, ou seja, a capacidade de autorreflexão. O resultado

\section{POLÊM!CA $\mid$ LABORË}

Polêmica - Revista Eletrônica da Uerj - Rua São Francisco Xavier, 524, $1^{\circ}$ andar bloco D, sl.1001 • Tels.: +55 21 2334-4088/4087 • http://www.e-publicacoes.uerj.br/index.php/polemica/index http://www.labore.uerj.br • laboreuerj@yahoo.com.br 
é o uso cada vez menor e menos intenso da rede como função especular da sua existência (MADUREIRA, 2015).

Sublinhamos que as funções de integração e reintegração se complementam e frequentemente andam juntas. Ao aparecem nas relações humanas, significa que pelo menos um dos membros têm condições de maturidade e disponibilidade para funcionar como veraz e confiável, de modo a se tornar apto a reconhecer e revelar traços de qualidades reais do outro, graças ao afeto, interesse e atenção individualizada que lhe dedica. Nesse sentido, se o espelho humano é integrador, ele consegue organizar e transmitir, consciente ou inconscientemente, uma imagem razoavelmente fiel, equilibrada e definida da outra pessoa que, por sua vez, pode identificar-se autenticamente com tal imagem, capturada por via consciente ou inconsciente (DOIN, 1987).

Se na vida do bebê o olhar de quem exerce a função materna é essencial para dar um lugar de existência ao sujeito (WINNICOTT, 1969), no universo das instafitness, o que se nota é que é justamente o olhar virtual contínuo de suas seguidoras que possibilita construir um caminho rumo à visibilidade. Se o bebê empreende um penoso esforço no sentido de ser visto por seu cuidador e ser reconhecido em sua presença (WINNICOTT, 1969), um movimento muito similar ocorre nas vidas dessas mulheres ao postarem diariamente a sua vida fitness no formato de tela nas redes sociais. Existe aqui uma intenção muito clara em se fazer ser vista pelo outro, que ganha uma dimensão primária em suas vidas, na medida em que, através do seu olhar, cria condições que asseguram um lugar para elas (instafitness) existam no mundo.

Esse lugar, ainda que virtual, parece oferecer mais simpatia e ternura do que o mundo off-line. Portanto, se trata de um olhar que propicia a criação de um espaço seguro para que elas possam ser quem são e, ao mesmo tempo, errarem quantas vezes forem necessárias, sem o julgamento alheio, até concretizarem o objetivo que as une na rede: emagrecer. Portanto, a rede social passa a ocupar um lugar de proteção e estabilidade. Se o olhar materno reflete o contorno corpóreo do bebê, conferindo-lhe existência no mundo, é interessante notar o quanto o olhar do outro virtual confirma a existência de uma vida dentro do universo dessas mulheres assoladas pelo sofrimento de exclusão e invisibilidade social em virtude do aspecto gorduroso.

Ao serem curtidas, comentadas e compartilhadas, essas mulheres obesas são notadas, contempladas e, em certa maneira, assistidas por esse outro. Com isso, retornamos à ideia winnicottiana (1969) de que, ao ser visto com cuidado, isto é, alimentado biológica e

\section{POLÊM!CA | LABORË}

Polêmica - Revista Eletrônica da Uerj - Rua São Francisco Xavier, 524, $1^{\circ}$ andar

bloco D, sl.1001 • Tels.: +55 21 2334-4088 / 4087 • http://www.e-publicacoes.uerj.br/index.php/polemica/index http://www.labore.uerj.br • laboreuerj@yahoo.com.br 
emocionalmente, o bebê torna-se vivo. No universo das instafitness, ao serem olhadas com zelo, dedicação e afeto, o que se percebe é que isso se torna um combustível poderoso, na medida em que lhes confere uma existência no mundo. Consequentemente, ao receberem olhares tenros e afetivos na rede social, que refletem um cuidado de quem olha, observa e testemunha o seu sofrimento e a sua transformação, permitem-se olhar para si mesmas com o mesmo sentimento e percepção.

Quando olho, sou visto; logo, existo. Posso agora me permitir olhar e ver. Olho agora criativamente e sofro a minha apercepção e também percebo, na verdade, protejo-me de não ver o que ali não está para ser visto (a menos que esteja cansado) (WINNICOTT, 1967, p. 180).

Isso faz com que ganhem uma nova forma de ser e existir no mundo, muito mais afetuosa para com si mesmas, pois existe um outro que as percebe, contempla e, sobretudo, está ali, ainda que no ambiente virtual, para que possam projetar as suas dores, angústias e sofrimentos com relação à gordura. Isso significa que esse outro virtual "está ali para "o que der e vier" ou que "pode contar com eles" (expressão usada pelas próprias instafitness). Dentro de uma sociedade cada vez mais lipofóbica, cuja anorexia branda ganha um status de positivo, e que associa gordura à falha de caráter (NOVAES, 2010), encontrar um espaço de compreensão que fornece uma possibilidade de diálogo e continente acerca da impossibilidade de se enquadrar nesse imperativo de modelo social de corpo magro, torna-se não apenas um alívio, mas uma forma de escoamento da sua intensa e dolorosa aflição.

É interessante notar o quanto o espaço virtual ganha uma dimensão de espelho que reflete o que o outro observa acerca da imagem que é compartilhada de si, cujos conteúdos mais frequentes são selfies corporais e fotos da rotina alimentar e de exercícios físicos (na academia ou em espaços públicos). Assim sendo, esse olhar que me observa retrata as minhas próprias aflições, medos relacionados à solidão, fracasso, humilhação, ameaça e morte subjetiva. É fundamental observar o quanto o olhar do universo off-line reproduz um ambiente hostil e repleto de ameaças inomináveis que ecoam no mundo interno do sujeito como catastróficos e, o universo online, por outro lado, parece refletir um lugar muito mais caloroso, hospitaleiro e cuidadoso para com a sua dor.

Nesse sentido, a provisão ambiental virtual parece ser muito mais positiva do que a offline, na medida em que reflete um cuidado acerca do sujeito. Winnicott (1967) nos lembra que

\section{POLÊM!CA | LABORE}

Polêmica - Revista Eletrônica da Uerj - Rua São Francisco Xavier, 524, $1^{\circ}$ andar bloco D, sl.1001 • Tels.: +55 21 2334-4088 / 4087 • http://www.e-publicacoes.uerj.br/index.php/polemica/index http://www.labore.uerj.br • laboreuerj@yahoo.com.br 
nas primeiras fases do desenvolvimento emocional do bebê humano, o papel desempenhado pelo ambiente é fundamental. Isso significa que se ninguém está ali para desempenhar a função do cuidado materno, a tarefa desenvolvimental do bebê torna-se infinitamente mais complicada. Em outras palavras, a função ambiental de segurar (holding), manejar (handling) e apresentar os objetos de forma parcial e cuidadosa, que reflita uma preocupação na integração subjetiva do bebê com relação ao ambiente e aos objetos que lhe são apresentados, fornece uma possibilidade de integrar subjetivamente o mundo que o cerca de modo muito mais consistente e seguro. Isto porque a sua experiência necessária e legítima de onipotência não é violada.

Paralelamente, no universo das instafitness, se o ambiente virtual exerce uma função de acolhimento ao invés de retaliação, um espaço seguro é criado, como uma espécie de continente protegido que permite a projeção de diversos sentimentos que permeiam a vida dessas mulheres em constante sofrimento por estarem acima do peso e, principalmente, as implicações subjetivas que isso suscita em suas vidas. Se o olhar virtual se adapta às necessidades dessas mulheres, relacionadas à insegurança com relação ao seu corpo e, consequentemente, ao seu eu, o que se nota é que esse mesmo olhar virtual passa a exercer uma função de holding (em suas devidas proporções) em suas vidas. Ao cuidar dessas mulheres, através de contínuas curtidas e comentários tecidos em suas fotos, cujo teor reflete incentivo, admiração e torcida, o olhar virtual positiva as suas inexistências e, com isso, lhes confere um lugar de existência no mundo.

Ainda que em uma outra dimensão, o que se percebe é que as seguidoras exercem uma função de ambiente acolhedor que não fere ou machuca essas mulheres, tal como é o ambiente off-line. Longe disso, elas parecem exercer um papel de holding, na medida em que recebem e correspondem à enxurrada de sentimentos angustiantes projetados pelas instafitness, principalmente porque suas atitudes estão ausentes de julgamento ou crítica com relação ao corpo obeso dessas mulheres. Nesse sentido, parece-nos que se tornam seguidoras suficientemente boas, uma vez que se colocam como continente seguro para que se possa projetar infinitamente, e quantas vezes mais forem necessárias, os sentimentos de aflição e agonia da exclusão social que reflete o corpo do sujeito obeso, visto como defeituoso, incontrolável, vil e indecoroso (NOVAES, 2006).

A ser justamente o olhar materno, através do sentido que confere à sua existência, que acarreta uma organização psíquica do mundo interno caótico do bebê, então ele se torna

\section{POLÊM!CA | LABORÊ}

Polêmica - Revista Eletrônica da Uerj - Rua São Francisco Xavier, 524, $1^{\circ}$ andar

bloco D, sl.1001 • Tels.: +55 21 2334-4088/4087 • http://www.e-publicacoes.uerj.br/index.php/polemica/index http://www.labore.uerj.br • laboreuerj@yahoo.com.br 
essencial para a fundação da subjetividade do sujeito humano (WINNICOTT, 1969). Ainda que as instafitness já tenham se constituído subjetivamente, o que se percebe é que o universo offline não cria condições que possam espelhar a sua subjetividade de uma forma positiva. Por isso, o espelho acaba constituindo-se como algo a ser olhado e não examinado, o que reflete um sentimento de dificuldade com relação aos espelhos, sobretudo com o que ele tem a oferecer, frequentemente da ordem da deslegitimação e do negativo. Assim sendo, o espelho funciona como desorganizador, de modo a induzir a construção de uma barreira defensiva para com o mundo que hostiliza a existência desse sujeito.

Ao investigar o seu rosto, ou melhor, o seu corpo no espelho metaforizado pela vitrine virtual, o sujeito obeso finalmente adquire tranquilidade ao sentir que existe alguém (ou muitos) - seguidoras suficientemente boas - que refletem a sua imagem, reconhecem a sua dor e, como resultado, positivam a sua existência. Ao verem a sua imagem refletida no espelho, conseguem, pela primeira vez em suas vidas, acreditar que é possível emagrecer e construir uma outra narrativa que retrate os seus momentos de alegria e conquista. Ou seja, somente através do vínculo que estabelecem com as suas seguidoras suficientemente boas, essas mulheres conseguem mudar o rumo da sua história (eliminar uma grande quantidade de gordura) e, finalmente, ocupar um outro lugar em suas vidas familiares, profissionais e sociais.

Dessa maneira, percebe-se que a rede virtual ganha uma dimensão de espaço potencial e que, ao compartilharem as suas vidas no Instagram, as instafitness constroem um espaço de brincadeira adulta. O brincar implica em confiança e pertence especificamente ao espaço potencial que se configura na relação entre mãe e bebê, em um estado de dependência quase que absoluta e, por isso, com a função adaptativa da figura materna, que ganha contorno de previsível para o bebê (WINNICOTT, 1975, p. 63).

É no brincar, e somente no brincar, que a criança, ou o adulto, fruem a sua liberdade de criação. A importância desse conceito reside na diferença entre duas realidades, ainda não apreendidas subjetivamente pelo bebê: realidade psíquica, isto é, interna e uma realidade externa, localizada no ambiente que circunda o sujeito. O espaço potencial é uma terceira área extremamente valiosa que se localiza entre o bebê e a mãe. $\mathrm{O}$ brincar localiza-se nessa área entre os sujeitos e é essencial porque nele o sujeito manifesta o seu potencial criativo (WINNICOTT, 1971).

\section{POLÊM!CA $\mid$ LABORE}

Polêmica - Revista Eletrônica da Uerj - Rua São Francisco Xavier, 524, $1^{\circ}$ andar bloco D, sl.1001 • Tels.: +55 21 2334-4088/4087 • http://www.e-publicacoes.uerj.br/index.php/polemica/index http://www.labore.uerj.br • laboreuerj@yahoo.com.br 
No cenário das instafitness, certas condições se fazem necessárias para que se possa exercer adequada e satisfatoriamente o potencial criativo. Alcançar o sucesso em sua busca pela eliminação de gordura nos parece que implica exercer a sua criatividade através do jogo simbólico de espelhos e vitrines das redes sociais. Se é no brincar, e somente no brincar, que a criança ou adulto consegue exercer o seu potencial criativo, isso se dá em virtude da utilização da sua personalidade integral, o que significa dizer que é somente sendo criativo que o sujeito descobre o seu eu (self) (WINNICOTT, 1969).

Na postagem diária de imagens de si, o que essas mulheres fazem nada mais é do que utilizar a rede social como um espaço potencial de brincadeira (adulta) entre ela e o outro(s) que a segue. Nesse contexto, me parece que o jogo simbólico de fotografias partilhadas consiste justamente no brincar adulto, que só ganha potencialidade na medida em que se dirige e é correspondido positivamente por esse outro virtual, que dá um sentido a esse jogo de imagens. Por meio desse jogo criativo, essas mulheres exercem a sua potencialidade de tal modo que conseguem eliminar uma grande quantidade de gordura de forma inesperada, inclusive para elas mesmas, em um curto espaço de tempo.

É interessante notar o quanto a brincadeira adulta permite a construção de uma ponte para a liberdade de criação. No caso das instafitness, a brincadeira localiza-se no cenário virtual, que cria condições para que se exerça, a partir do compartilhamento diário e intenso de sua dor de ser obesa, a sua liberdade criativa. É fundamental sublinhar que a potencialidade criativa dessas mulheres só pode ser operada na medida em que esse ambiente virtual se comporta de maneira a receber sem retaliar a projeção de sentimentos dolorosos acerca da implicação que a gordura tem em suas vidas, sobretudo no que tange à sua feminilidade. Afinal de contas, ser feminina no mundo contemporâneo é ser magra e jovem (VILHENA, NOVAES, 2012). Portanto, a possibilidade do brincar na rede se torna essencial para que essas mulheres consigam manifestar a criatividade e, consequentemente, modificar a sua forma de ser e estar no mundo. Essa radical mudança em suas vidas reflete um eu (self) que se edifica através do olhar das seguidoras suficientemente boas que ratificam a sua nova forma de ser através da busca pelo emagrecimento partilhada pela performance imagética.

A partir do somatório das experiências positivas que ocorrem sucessivamente dentro do ambiente virtual, que ganha status de suficientemente bom, uma base para o eu (self) enfraquecido se erige. Esse eu frágil ganha robustez e vitalidade na medida em que uma

\section{POLÊM!CA | LABORẸ}

Polêmica - Revista Eletrônica da Uerj - Rua São Francisco Xavier, 524, $1^{\circ}$ andar

bloco D, sl.1001 • Tels.: +55 21 2334-4088/4087 • http://www.e-publicacoes.uerj.br/index.php/polemica/index http://www.labore.uerj.br • laboreuerj@yahoo.com.br 
comunicação efetiva pôde se estabelecer entre as instafitness e as seguidoras suficientemente boas. É justamente essa comunicação, manifestada na possibilidade da brincadeira virtual (compartilhamento de selfies do corpo e da alimentação), que se pode criar condições para se fortalecer o eu (self) do sujeito obeso, caracterizado por insegurança e ausência de vitalidade, em virtude do excesso de exclusão social de que foi alvo ao longo de sua vida.

É importante frisar que esta é apenas uma das infinitas possibilidades que cada sujeito pode fazer para buscar o emagrecimento. O que se nota, entretanto, é que essa é uma opção que se oferece na contemporaneidade e que se dá, especificamente, através do uso de uma ferramenta virtual. Além disso, faz-se importante esclarecer que nem todas as mulheres que exploram esse espaço virtual, cuja potência é significativamente alta, conseguem emagrecer ou fortalecer o seu self. Cada trajetória em busca da eliminação de gordura é única, na medida em que cada sujeito reflete as suas marcas singulares e os seus traços psíquicos. O uso que será feito do Instagram, portanto, é igualmente ímpar e representa resultados que refletem a sua subjetividade e labuta em busca desse objetivo.

\section{Considerações finais}

A experiência cultural que se localiza no espaço potencial (ambiente virtual da rede Instagram) existente entre as instafitness e as seguidoras suficientemente boas funciona como uma mola propulsora para a experiência criativa (implicações e formas para se lidar com a gordura) e, em longo prazo, como um estímulo para o viver criativo, que inicialmente se manifestou na brincadeira de postar autoimagens de suas árduas lutas em busca da eliminação de peso. O uso que fazem desse espaço é determinado pelas experiências de vida dessas mulheres e nos parece ser um uso bastante positivo e transformador em suas vidas, uma vez que reduz o sofrimento sem contudo ignorá-lo. Funcionando como continente de projeção e apoio, sem retaliação para o seu movimento de busca por um lugar social, o eu (self) se fortalece e ganha novo contorno em virtude do surpreendente e inesperado afeto que recebe no ambiente virtual.

Por isso, a ideia de que esse espaço específico da rede, compreendido como um espaço potencial se torna um ambiente virtual suficientemente bom, repleto de seguidoras suficientemente boas que promovem experiências acolhedoras e afetuosas para com essas mulheres, parece fazer muito sentido. É justamente a adaptação às necessidades das instafitness

\section{POLÊM!CA $\mid$ LABORE}

Polêmica - Revista Eletrônica da Uerj - Rua São Francisco Xavier, 524, $1^{\circ}$ andar bloco D, sl.1001 • Tels.: +55 21 2334-4088/4087 • http://www.e-publicacoes.uerj.br/index.php/polemica/index http://www.labore.uerj.br • laboreuerj@yahoo.com.br 
que possibilita uma revitalização do eu (self), há muito fragilizado em virtude do constante lugar de exclusão social aferido.

Se ao postar sou vista, e logo existo; isso significa que o meu corpo e a minha imagem passam a ser vistas, contempladas e refletidas. É isso que confere um lugar de existência no mundo para essas mulheres, antes invisíveis ou vistas de forma negativa. A soma de experiências do mundo off-line as conduziu a um lugar de exclusão e, portanto, de defesa com relação ao julgamento e golpes desferidos pelo mundo. No entanto, um novo sentimento de confiança pode ser construído a partir da comunicação afetuosa e estável que se estabelece no espaço potencial da rede social entre as instafitness e as seguidoras suficientemente boas, que ocorre basicamente através da brincadeira adulta de postar imagens de si própria na rede.

Isso se torna o alimento e combustível para que o eu (self) possa construir meios de viver criativamente as suas experiências e fazer algo de positivo da sua existência. Se o espaço potencial erigir um sentimento de confiança, fidedignidade e estabilidade emocional, logo o sujeito constrói instrumentos suficientes para edificar uma autorrealização vigorosa e relaxada. Um fracasso na confiança do ambiente resulta em uma restrição à capacidade lúdica do sujeito, devido às limitações do espaço potencial, o que reflete em uma pobreza nas brincadeiras e na vida cultural. Um sentimento de desconfiança se instala e o brincar criativo não acontece (WINNICOTT, 1969).

É fundamental sublinhar que o uso das redes sociais com a finalidade de emagrecer pode ou não se dar na vida dessas mulheres. Muitas, inclusive, fazem tentativas e não obtém êxito. Isso significa que nem todas as mulheres que utilizam o Instagram irão, de fato, emagrecer. Não existe o "milagre" das seguidoras suficientemente boas ou do próprio aplicativo. O que existe, porém, é uma outra possibilidade de percurso para emagrecer, que inclua, talvez, mais chances de êxito, a partir da experiência de ser vista por um olhar social mais acolhedor e afetuoso, que é da ordem do virtual. É inegável que as condições subjetivas do sofrimento deixam marcas indeléveis no sujeito e que a luta para eliminar gordura é muito árdua, dolorosa e laboriosa, independente da forma com a qual se dá ou do caminho escolhido.

Assim sendo que, para algumas pessoas, o emagrecimento através da rede virtual não será possível, tendo em vista que este primeiro olhar não se deu ou se deu de forma muito precária e deficitária. No entanto, parece-nos que a tecnologia traz uma nova maneira de ser olhada e, com isso, emagrecer. Ferramentas virtuais, tais como o Instagram, podem funcionar

\section{POLÊM!CA | LABORE}

Polêmica - Revista Eletrônica da Uerj - Rua São Francisco Xavier, 524, $1^{\circ}$ andar

bloco D, sl.1001 • Tels.: +55 21 2334-4088/ 4087 • http://www.e-publicacoes.uerj.br/index.php/polemica/index http://www.labore.uerj.br • laboreuerj@yahoo.com.br 
como uma nova aposta justamente por trabalhar questões relacionadas ao olhar, que funciona como aquele que legitima ou não a existência do sujeito. Ou seja, esse olhar pode positivar ou negativizar a existência a partir da qualidade da relação que se constrói via tecnologia.

\section{Referências}

CARVALHO, P.S. Interação entre humanos e computadores: uma introdução. São Paulo: EDUC. 2000.

DOIN, C. O espelho e a pessoa. In: FILHO, J. M (org.). O ser e o viver: uma visão na obra de Winnicott. Casa do Psicólogo, 2001.

Reflexões sobre o Espelho. Apresentado na reunião científica da SBPRJ. 12 jan. 1987.

LEVY, P. Cibercultura. São Paulo: Editora 34,1999.

ASSUNÇÃO, A.B. \& JORGE, T.M. As mídias sociais como tecnologias de si. Revista Esferas, Brasília. 2014. Disponível em: <https://portalrevistas.ucb.br/index.php/esf/article/view/5331〉. Acesso em: 10 jul. 2017.

COELHO, P.G.N. Compartilho, logo sou: a construção de identidades no uso do Instagram. Congresso Internacional de Comunicação e Consumo. ESMP. São Paulo. 2016. Disponível em: <http://anaiscomunicon2016.espm.br/GTs/GTPOS/GT2/GT02-PIETRO_COELHO.pdf>. Acesso em: 10 jul. 2017.

MADUREIRA, B. Vagas para moças de fina estampa: padrões estéticos e seleção no comércio da moda carioca. Dissertação de mestrado. Departamento de Psicologia. Pontifícia Universidade Católica - PUCRio.2013.

As Barbies do Varejo: um estudo acerca dos padrões estéticos dos processos de seleção do comércio da moda carioca. Revista Eletrônica Polêm!ca., Rio de Janeiro, v. 15, n. 1, abr./jun. 2015. Disponível em: <http://www.e-publicacoes.uerj.br/index.php/polemica/article/view/16007/12058>. Acesso em: 28 jul. 2017.

MADUREIRA, B. Qualificação de Doutorado. Departamento de Psicologia da PUC-Rio. 2015.

NOVAES, J. O intolerável peso da feiúra: sobre as mulheres e seus corpos. Rio de Janeiro: PUC/Garamond. 2006.

SIBÍLIA, P. O show do eu: a intimidade como espetáculo. Rio de Janeiro: Nova Fronteira. 2008. n. 1,2008 .

O universo doméstico na era da extimidade: Nas artes, nas mídias e na internet. Revista Eco Pós. v. 18,

VILHENA, J.; NOVAES, J. (orgs). Com que corpo eu vou? Sociabilidade e usos do corpo nas mulheres das camadas altas e populares. Rio de Janeiro: PUC/Pallas. 2010.

(orgs). Corpo para que te quero? Usos, abusos e Desusos. Rio de Janeiro: Appris/PUC. 2012.

VILHENA, J.; NOVAES, J.; ROSA, C.M. Tempos de envelhecer: corpo, memória e transitoriedade In: VILHENA, J.; NOVAES, J. Que corpo é este que anda sempre comigo? Corpo, imagem e sofrimento psíquico. 1 ed. Curitiba: Appris, 2016, v.1, p. 147-164.

WINNICOTT, D. O papel de espelho da mãe e da família no desenvolvimento infantil. In: WINNICOTT, D.W. O brincar e a realidade. Rio de Janeiro: Imago, 1967. p. 153-162.

\section{POLÊM!CA $\mid$ LABORE}

Polêmica - Revista Eletrônica da Uerj - Rua São Francisco Xavier, 524, $1^{\circ}$ andar bloco D, sl.1001 • Tels.: +55 21 2334-4088/4087 • http://www.e-publicacoes.uerj.br/index.php/polemica/index http://www.labore.uerj.br • laboreuerj@yahoo.com.br 
O uso de um objeto e relacionamento através de identificações. In: WINNICOTT, D.W. O brincar e a realidade. Rio de Janeiro: Imago, 1969. p. 121-131.

O brincar: uma exposição teórica. In: WINNICOTT, D.W. O brincar e a realidade. Rio de Janeiro: Imago, 1971. p. 59-77.

A criatividade e suas origens. In: WINNICOTT, D.W. O brincar e a realidade. Rio de Janeiro: Imago, 1971. p. 95-120.

Recebido em: 25/03/2018.

Aceito em: 04/06/2018.

\section{POLÊM!CA LABORE}

Polêmica - Revista Eletrônica da Uerj - Rua São Francisco Xavier, 524, $1^{\circ}$ andar bloco D, sl.1001 • Tels.: +55 21 2334-4088/4087 • http://www.e-publicacoes.uerj.br/index.php/polemica/index http://www.labore.uerj.br • laboreuerj@yahoo.com.br 